\begin{tabular}{|c|c|c|}
\hline Case Reports in & \multicolumn{2}{|c|}{ Case Rep Gastroenterol 2017;11:162-167 } \\
\hline Gastroenterology & $\begin{array}{l}\text { DOI: 10.1159/000456607 } \\
\text { Published online: Vlarch 21, } 2017\end{array}$ & $\begin{array}{l}\text { () } 2017 \text { The Author(s) } \\
\text { Published by S. Karger AG, Basel } \\
\text { www.karger.com/crg }\end{array}$ \\
\hline & $\begin{array}{l}\text { This article is licensed under the } \\
\text { International License (CC BY-NC) } \\
\text { Usage and distribution for commer }\end{array}$ & $\begin{array}{l}\text { nons Attribution-NonCommercial } 4.0 \\
\text { ger.com/Services/OpenAccessLicense). } \\
\text { uires written permission. }\end{array}$ \\
\hline
\end{tabular}

\title{
Bacterial Ulcerative Esophagitis in an Immunocompetent Patient
}

\author{
Jung A. Shin ${ }^{a}$ Young Bae Lee ${ }^{a}$ In Cheol Yoon ${ }^{a}$ Hyeon Ju Jeong ${ }^{a}$ \\ Taejung Kwon $^{b}$ Hong Sub Lee ${ }^{a}$ \\ ${ }^{a}$ Department of Internal Medicine, Seonam University College of Medicine, Myongji \\ Hospital, Goyang, South Korea; ${ }^{b}$ Department of Pathology, Seonam University College of \\ Medicine, Myongji Hospital, Goyang, South Korea
}

\section{Keywords}

Esophagitis · Bacterial infections · Esophageal stenosis · Immunocompetent hosts

\begin{abstract}
Bacterial esophagitis is a very rare condition usually occurring in patients with immunosuppression. To our best knowledge, bacterial esophagitis without underlying immunosuppressive disease has not been reported. We report an immunocompetent patient with bacterial esophagitis caused by B-hemolytic Streptococcus which resulted in an esophageal stricture. A 68-year-old female was admitted for odynophagia which had developed several days before. Upper endoscopy revealed extensive ulceration covered by whitish exudates with submucosal edema at the proximal esophagus. She was treated with steroids and empirical broadspectrum antibiotics. Within 14 days the symptoms improved. Since growth of B-hemolytic Streptococcus was detected in nasal smear culture, bacterial esophagitis was suspected. Gram staining was carried out on the already obtained tissue that had been fixed with formalin. There was heavy infiltration with gram-positive cocci morphologically consistent with Streptococcus. Since the bacterial colony was demonstrated histologically, the diagnosis of bacterial esophagitis caused by B-hemolytic Streptococcus was confirmed. In addition, complete resolution of the inflammation following antibiotics therapy was further evidence of the bacterial cause of the esophagitis.

(C) 2017 The Author(s) Published by S. Karger AG, Basel
\end{abstract}




\section{Case Reports in Gastroenterology}

Case Rep Gastroenterol 2017;11:162-167

DOI: $10.1159 / 000456607$

(c) 2017 The Author(s). Published by S. Karger AG, Basel www.karger.com/crg

Shin et al.: Bacterial Ulcerative Esophagitis in an Immunocompetent Patient

\section{Introduction}

Infectious esophagitis is an uncommon condition caused by viral, bacterial, or fungal agents [1]. These infections can be seen usually in patients who have some types of immunosuppression including granulocytopenia, lymphopenia, and so on. Although infectious esophagitis is usually caused by infection with candida, herpesvirus, or cytomegalovirus, bacterial esophagitis is comparatively rare and occurs in $11-16 \%$ of cases of infectious esophagitis who have immunosuppression [2,3]. Bacterial esophagitis is characterized by endoscopically observable ulcers with erythema, exudate, and hemorrhage. Dominant symptoms including severe dysphagia and odynophagia occur. Furthermore, it may be a source of bacterial sepsis and require prompt antibiotic therapy.

To our best knowledge, bacterial esophagitis has not been reported without underlying disease. We report an immunocompetent patient with bacterial esophagitis caused by Bhemolytic Streptococcus which resulted in an esophageal stricture.

\section{Case Report}

A 68-year-old female was admitted to the ear-nose-throat department for odynophagia and oral pain which had developed several days before. She had no past history except for that of insomnia. At admission, laryngoscopy showed multiple whitish patchy lesions on the epiglottis and larynx. The lesions were diagnosed as acute epiglottitis and laryngitis. Consultation with the gastroenterology department was done because of odynophagia. Upper endoscopy revealed extensive ulceration covered by whitish exudates with submucosal edema at the proximal esophagus (Fig. 1). Microscopic section of the esophageal mucosa was obtained by upper endoscopic biopsy. On hematoxylin and eosin staining, there were inflammatory cell exudates without yeast, cellular inclusions, or giant cells. Although corrosive esophagitis was suspected, there was no personal history of ingestion of caustic substances. The etiology of esophagitis was not identified.

The patient was treated with steroids (dexamethasone $5 \mathrm{mg}$ intramuscular injection for 2 days) and empirical broad-spectrum antibiotics (flomoxef sodium $2 \mathrm{~g}$ twice per day for 14 days and isepamicin sulfate $500 \mathrm{mg}$ once daily for 7 days). Within 14 days, the symptoms of oral pain and odynophagia improved. However, dysphagia for solid food developed. Hence, consultation and transfer to the gastrointestinal department was conducted. Follow-up endoscopy showed improvement in inflammation, but stenosis at the level of the upper esophageal sphincter (Fig. 2). Growth of B-hemolytic Streptococcus was detected in nasal smear culture. Human immunodeficiency virus antibody was negative by enzyme-linked immunosorbent assay and tumor markers were within their normal range. Granulocytopenia was not observed. She did not have a history of previous esophageal surgery or obvious concurrent fungal, viral, or neoplastic involvement of the esophageal tissue, as demonstrated by negative biopsy at the time of endoscopy. Since the patient was immunocompetent, bacterial esophagitis was not suspected. After 2 weeks of treatment with antibiotics and proton pump inhibitor agents, she successfully recovered, but still had a benign stricture at the level of the upper esophageal sphincter. After 4 sessions of balloon dilatation $(8-13 \mathrm{~m})$ had been performed, her symptoms improved and she was discharged from the hospital. However, the dysphagia symptom recurred after 4 weeks. Hence, 3 sessions of balloon dilatation with steroid injection were performed. Finally, she could eat solid food very well and this condition was maintained for 6 months. 


\section{Case Reports in Gastroenterology}

Case Rep Gastroenterol 2017;11:162-167 DOI: $10.1159 / 000456607$

(c) 2017 The Author(s). Published by S. Karger AG, Basel www.karger.com/crg

Shin et al.: Bacterial Ulcerative Esophagitis in an Immunocompetent Patient

The symptoms and inflammation caused by her esophagitis improved clinically and endoscopically after antibiotic therapy and proton pump inhibitor treatment. However, acid reflux was ruled out since the extent of esophagitis was from the larynx to the upper esophagus and not to the lower esophagus and esophagogastric junction. Based on clinical features including nasal smear findings, bacterial esophagitis was suspected. Gram staining was carried out on the formalin-fixed tissue. There was heavy infiltration with gram-positive cocci morphologically consistent with Streptococcus (Fig. 3). Since the bacterial colony was demonstrated histologically, the diagnosis of bacterial esophagitis caused by B-hemolytic Streptococcus was confirmed. In addition, the complete resolution of the inflammation following antibiotics therapy was further evidence of the bacterial cause of the esophagitis.

\section{Discussion}

Bacterial esophagitis is most commonly reported in association with conditions or diseases that weaken the immune system, such as iatrogenic immunosuppression after bone marrow transplantation [3], severe neutropenia [2], hematologic malignancies [4], human immunodeficiency virus infection [5], and lymphocytopenia [6].

The most significant risk factor is granulocytopenia. Odynophagia is common along with retrosternal pain, but fever is characteristically absent. Endoscopy findings include mucosal friability, ulcerations, and pseudomembranes [7]. The major organisms are usually the normal flora of the mouth and the upper respiratory system. These include Staphylococcus aureus, Staphylococcus epidermidis, Streptococcus viridans, and Bacillus species [8]. Although bacterial esophagitis has not been well characterized, Walsh et al. [2] defined it as histopathologically demonstrable bacterial invasion of esophageal mucosa or deeper layers with no concomitant fungal, viral, or neoplastic involvement or previous surgery of the esophagus. Howlett [9] reported that an exudative inflammatory reaction was observed at the esophagus, and they confirmed the presence of bacteria through endoscopic mucosal biopsy. Bacterial esophagitis can be diagnosed when bacterial colonies infiltrate the subepithelial tissue. In addition, Walsh et al. [2] reported that among 23 cases of bacterial esophagitis, there were 4 cases of bacteremia. These cases of bacteremia seemed to be caused by esophagitis and were confirmed by tissue culture. Optimal histological features are noted when the studied section is stained using the Gram stain under oil immersion lens. Thus, hematoxylin and eosin staining alone is not sufficient to observe bacteria. Endoscopic bacterial culture tests are generally not performed in most endoscopic rooms because endoscopic bacterial contamination cannot be avoided and invasive esophagitis rarely occurs in practice. A study by Norder Grusell et al. [10], in which samples were collected from the esophageal mucosa of patients without endoscopic signs of esophageal disease, showed that the normal esophagus is colonized with a resident bacterial flora of its own, with the most frequent inhabitants being streptococci, present in $95-98 \%$ of cases. Interpretation of culture results is therefore difficult, and occasionally it may indicate contamination. In the areas of mucosal disruption secondary to acid reflux, viral or fungal pathogens may colonize, with bacteria acting as secondary invaders. Therefore, physicians should perform tissue culture and interpret the results carefully in cases of suspicious bacterial esophagitis.

In general, it is recommended that bacterial infection caused by oral flora in a healthy person be treated with beta-lactam combined with aminoglycoside broad-spectrum antibiotics. In addition, the use of appropriate antibiotics on the basis of clinical features and culture results has been encouraged. 
In contrast to the other causes of infectious esophagitis, the treatment of bacterial esophageal infection includes antibiotics, hence accurate diagnosis is essential. Successful treatment of bacterial esophagitis requires appropriate, empirical antimicrobial therapy. The response to antibacterial therapy appears to be favorable [2, 7].

The presence of esophageal symptoms is a clear indication for endoscopy, culture, and biopsy for determining the underlying cause. Bacterial esophagitis should be strongly considered in such patients, particularly in those who have infectious esophagitis without viral or fungal infection.

To date, there has been no reported case of bacterial esophagitis in immunocompetent patients in the literature. We present this case to suggest that esophagitis of unknown origin in immunocompetent patients be considered as bacterial esophagitis. Increased awareness of this clinical feature and endoscopic review may help in making an early diagnosis and therapy initiation.

It is obvious that more studies are needed to establish the frequency of true bacterial esophagitis among cases of esophagitis of unknown origin.

\section{Statement of Ethics}

This article does not contain any studies with human or animal subjects performed by any of the authors.

\section{Disclosure Statement}

The authors have no financial disclosure to report.

\section{Author Contributions}

J.A. Shin wrote the manuscript. Y.B. Lee, I.C. Yoon, H.J. Jeong, and T. Kwon revised the manuscript. H.S. Lee critically revised the manuscript and is the guarantor.

\section{References}

-1 O’Rourke A: Infective oesophagitis: epidemiology, cause, diagnosis and treatment options. Curr Opin Otolaryngol Head Neck Surg 2015;23:459-463.

- Walsh TJ, Belitsos NJ, Hamilton SR: Bacterial esophagitis in immunocompromised patients. Arch Intern Med 1986;146:1345-1348.

-3 McDonald GB, Sharma P, Hackman RC, Meyers JD, Thomas ED: Esophageal infections in immunosuppressed patients after marrow transplantation. Gastroenterology 1985;88:1111-1117. Givler RL: Esophageal lesions in leukemia and lymphoma. Am J Dig Dis 1970;15:31-36.

Bonacini M, Young T, Laine L: The causes of esophageal symptoms in human immunodeficiency virus infection. A prospective study of 110 patients. Arch Intern Med 1991;151:1567-1572.

Richert SM, Orchard JL: Bacterial esophagitis associated with CD4+ T-lymphocytopenia without HIV infection. Possible role of corticosteroid treatment. Dig Dis Sci 1995;40:183-185.

7 Ezzell JH Jr, Bremer J, Adamec TA: Bacterial esophagitis: an often forgotten cause of odynophagia. Am J Gastroenterol 1990;85:296-298.

-8 Baehr PH, McDonald GB: Esophageal infections: risk factors, presentation, diagnosis, and treatment. Gastroenterology 1994;106:509-532.

- Howlett SA: Acute streptococcal esophagitis. Gastrointest Endosc 1979;25:150-151. 


\section{Case Reports in \\ Gastroenterology}

\begin{tabular}{l|l}
\hline Case Rep Gastroenterol 2017;11:162-167 \\
\hline DOI: $10.1159 / 000456607$ & $\begin{array}{l}\text { C 2017 The Author(s). Published by S. Karger AG, Basel } \\
\text { www.karger.com/crg }\end{array}$ \\
\hline
\end{tabular}

Shin et al.: Bacterial Ulcerative Esophagitis in an Immunocompetent Patient

10 Norder Grusell E, Dahlen G, Ruth M, Ny L, Quiding-Jarbrink M, Bergquist H, Bove M: Bacterial flora of the human oral cavity, and the upper and lower esophagus. Dis Esophagus 2013;26:84-90.

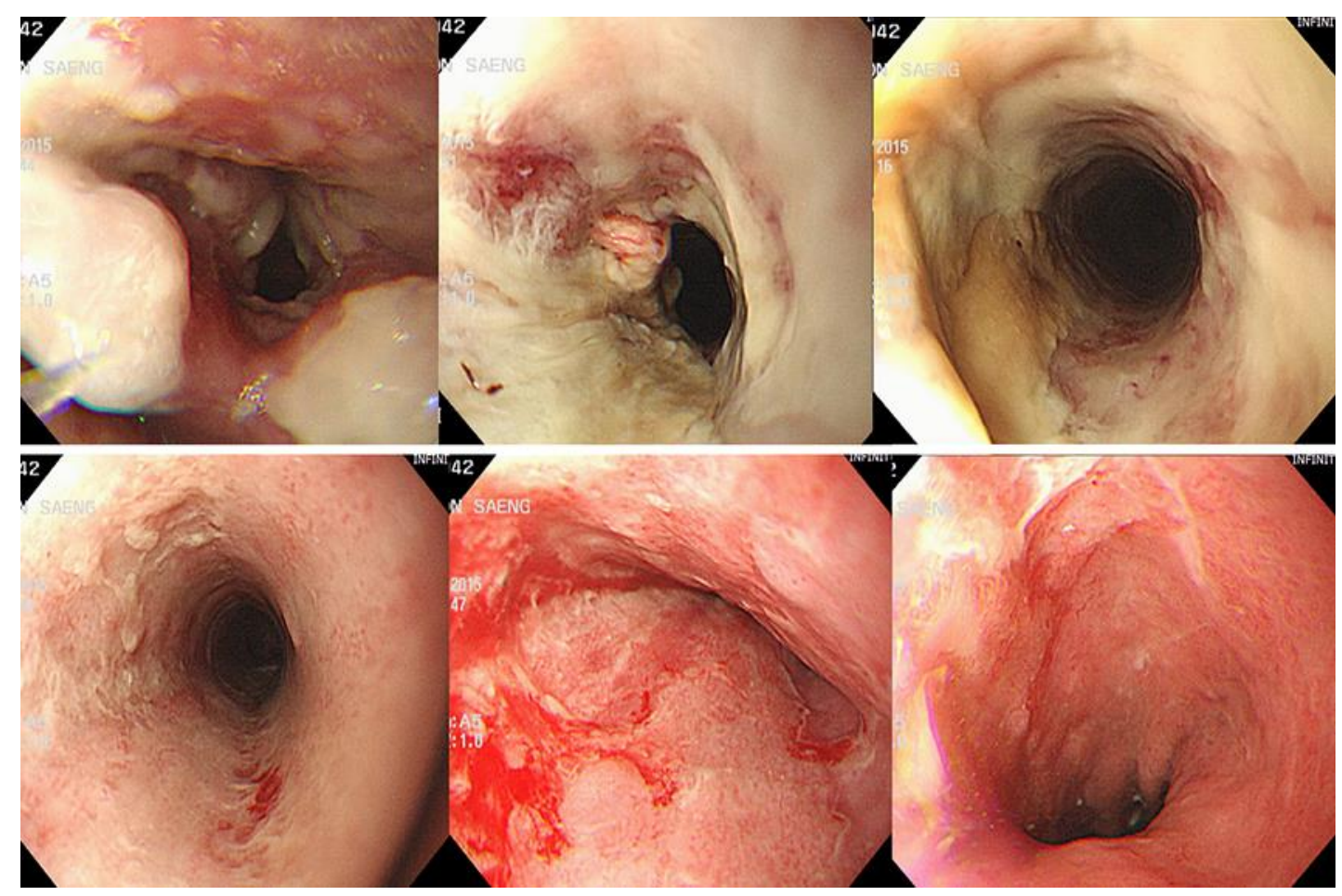

Fig. 1. Initial endoscopic findings. Upper endoscopy revealed extensive ulceration covered by whitish exudates with submucosal edema at the proximal esophagus. Erythematous change was noted on the lower esophagus. 


\section{Case Reports in Gastroenterology}
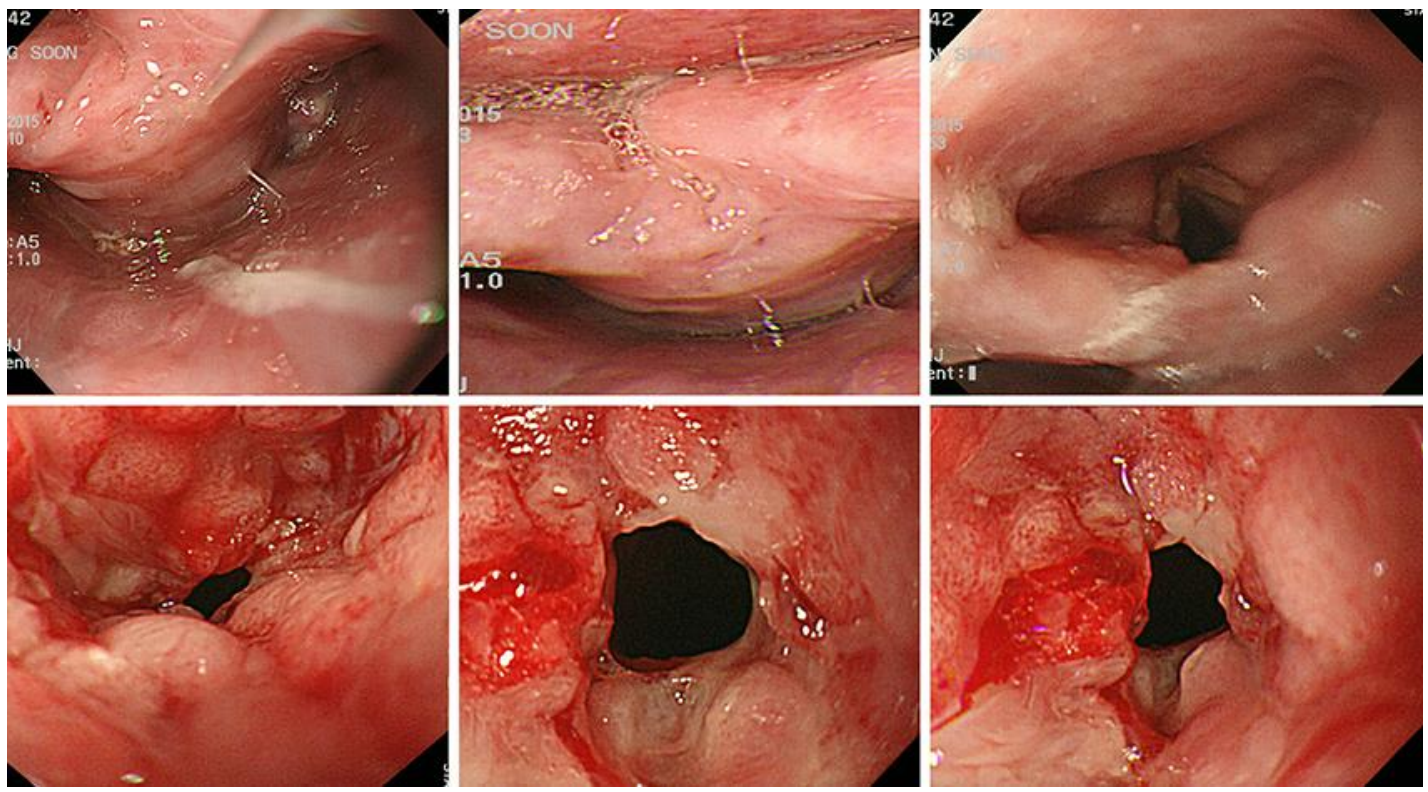

Fig. 2. Follow-up endoscopic findings. After 14 days, improvement in inflammation was found, but stenosis at the level of the upper esophageal sphincter had developed.
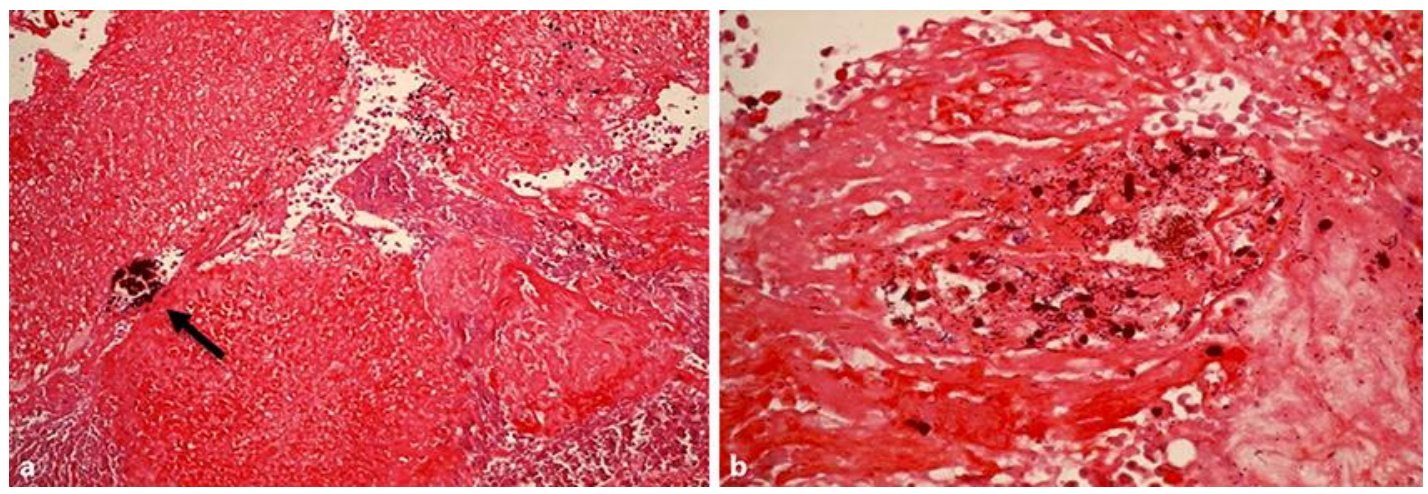

Fig. 3. Pathologic findings. a Microscopic finding shows Gram staining materials and necrotic tissues (Gram stain, $\times 100$ ). The arrow shows bacterial colony. b Magnifying (Gram stain, $\times 600$ ) microscopic findings shows heavy infiltration with gram-positive cocci morphologically consistent with Streptococcus. 